\title{
Casein Kinase 2 Determines the Voltage Dependence of the Kv3.1 Channel in Auditory Neurons and Transfected Cells
}

\author{
Carolyn M. Macica and Leonard K. Kaczmarek \\ Department of Pharmacology, Yale University School of Medicine, New Haven, Connecticut 06520-8066
}

The Kv3.1 potassium channel can be distinguished from most other delayed rectifier channels by its very high threshold of activation and lack of use-dependent inactivation. This allows neurons that express this channel to fire at very high frequencies. We have now found that this feature of the Kv3.1 channel is strongly influenced by its constitutive phosphorylation by the enzyme casein kinase II. Using stably transfected Chinese hamster ovary cells expressing Kv3.1, we show that Kv3.1 is highly phosphorylated under basal conditions. Whole-cell patch clamp recordings were used to characterize the electrophysiological consequence of dephosphorylation using alkaline phosphatase. This enzyme produced an increase in whole-cell conductance and shifted the voltage dependence of activation to more negative potentials by $>20 \mathrm{mV}$. In addition, a similar shift in the voltage dependence of inactivation was observed.
These findings were also confirmed in native Kv3.1 channels expressed in medial nucleus of the trapezoid body (MNTB) neurons. Furthermore, inhibitors of casein kinase 2 mimicked the effect of phosphatase treatment on voltage-dependent activation and inactivation, whereas inhibitors of protein kinase $\mathrm{C}$ failed to alter these parameters. The combination of biochemical and electrophysiological evidence suggests that the biophysical characteristics of Kv3.1 that are important to its role in MNTB neurons, allowing them to follow high-frequency stimuli with fidelity, are largely determined by phosphorylation of the channel.

Key words: Kv3.1; potassium channel; constitutive phosphorylation; casein kinase; MNTB neuron; voltage dependence of activation; voltage dependence of inactivation
Kv3.1 is a voltage-dependent, delayed rectifier potassium channel that is expressed in neurons that are capable of firing trains of action potentials at very high rates and is expressed at high levels in the auditory brainstem, including the medial nucleus of the trapezoid body (MNTB) (Perney et al., 1992; Weiser et al., 1995; Wang et al., 1998a,b). The Kv3.1 channel has several unique biophysical properties that distinguish it from most other members of the Shaker potassium channel family (Luneau et al., 1991; Vega-Saenz de Miera et al., 1992; Kanemasa et al., 1995). These include a high threshold for activation, rapid time constants, and the lack of use-dependent inactivation. All of these characteristics contribute significantly to its physiological role in MNTB neurons, where its presence is required for neurons to follow very high-frequency stimuli (Brew and Forsythe, 1995; Wang et al., 1998a). The presence of a Kv3.1-like current in MNTB neurons allows action potentials to repolarize at high frequencies without affecting the height of the action potential and confers on these cells the ability to phase-lock to high-frequency synaptic and electrical stimuli. This high-threshold $\mathrm{K}^{+}$current in MNTB is, like Kv3.1, selectively blocked by low concentrations of TEA, and has been identified with the Kv3.1 channel based on its localization, pharmacological, biophysical characteristics, and by genetic knock-out approaches (Perney et al., 1992; Brew and Forsythe, 1995; Perney and Kaczmarek, 1997; Wang et al., 1998a,b; Macica

\footnotetext{
Received March 13, 2000; revised Dec. 5, 2000; accepted Dec. 7, 2000.

This research was supported by National Institutes of Health Grant DC-01919 (L.K.K.) and National Research Service Award Fellowship MH12257-02 (C.M.M.). We thank Drs. Lu Yang-Wang, Neil Magoski, and Jennifer Ledwell for helpful discussion and technical advice.

Correspondence should be addressed to Leonard K. Kaczmarek, Department of Pharmacology, Yale University School of Medicine, 333 Cedar Street, New Haven, CT 06520. E-mail: leonard.kaczmarek@yale.edu.

Copyright (C) 2001 Society for Neuroscience 0270-6474/01/211160-09\$15.00/0
}

et al., 2000). Moreover, changing the amplitude of this current in MNTB neurons by pharmacological manipulation, or in computer-based models of MNTB neurons, reveals that altering the levels of Kv3.1 strongly influences the fidelity of the transmission of high-frequency synaptic inputs and the ability of the MNTB synapse to transmit information during repetitive stimulation (Brew and Forsythe, 1995; Kanemasa et al., 1995; Wang and Kaczmarek, 1998; Wang et al., 1998a).

The presence of multiple putative phosphorylation sites in the Kv3.1 amino acid sequence suggests that modulation of Kv3.1 may occur in MNTB neurons. We have now examined the modulation of Kv3.1 by protein kinases using both biochemical and electrophysiological techniques in Kv3.1 transfected cells and in neurons. We have found that the Kv3.1 channel protein exists as a constitutively phosphorylated protein and that the key biophysical parameters that allow Kv3.1 to function as a high-threshold current in rapidly firing neurons depend on this basal phosphorylation. Although previous work has shown that the amplitude of Kv3.1 may be modulated by protein kinase C (PKC) (Critz et al., 1993; Kanemasa et al., 1995), our present findings indicate that the basal characteristics of the current, including its voltage dependence of activation and inactivation are influenced by basal phosphorylation by casein kinase 2 (CK2).

\section{MATERIALS AND METHODS}

Electrophysiological recordings from Chinese hamster ovary cells. The stable transfection of Kv3.1 into Chinese hamster ovary (CHO) cells has been previously described (Wang et al., 1998a). CHO cells with DHFR deficiency $(\mathrm{CHO} / \mathrm{DHFR}(-))$ were maintained in Iscove's modified Aulbecco's medium (Life Technologies, Gaithersburg, MD) supplemented with $10 \%$ fetal bovine serum, $0.1 \mathrm{~mm}$ hypoxanthine, and $0.05 \mathrm{mg} / \mathrm{ml}$ geneticin (Life Technologies) and maintained in a $5 \% \mathrm{CO}_{2}$ incubator at $37^{\circ} \mathrm{C}$. CHO cells were grown on coverslips $24-48 \mathrm{hr}$ preceding recordings and transferred to extracellular solution (in mM: $140 \mathrm{NaCl}, 1.3 \mathrm{CaCl}_{2}, 5.4$ 
$\mathrm{KCl}, 25 \mathrm{HEPES}$, and 10 glucose, $\mathrm{pH}$ 7.4) $1 \mathrm{hr}$ before recording. Voltageclamp recordings were made in the whole-cell configuration, using an Axopatch 2D amplifier (Axon Instruments, Foster City, CA). The patch electrodes were pulled from thin-walled, borosilicate glass capillaries with filament (World Precision Instruments, Sarasota, FL) using a Narishige P-83 two-stage puller and had a resistance of $3 \mathrm{M} \Omega$ when filled with intracellular solution (in mM: $32.5 \mathrm{KCl}, 97.5 \mathrm{~K}$-Gluconate, 5 EGTA, and 10 HEPES, pH 7.2) supplemented with 2 mM ATP and $0.2 \mathrm{~mm}$ GTP, unless otherwise noted. For phosphatase experiments, $5 \mathrm{U}$ of calf intestinal alkaline phosphatase (Boehringer Mannheim, Indianapolis, IN) was included in the intracellular solution and allowed to dialyze into the cell over a period of $30 \mathrm{~min}$. All data were low-pass filtered at $2 \mathrm{kHz}$, digitized using a Digidata 2000 analog-to-digital converter (Axon Instruments), and were stored on hard disk. The compensation for series resistance was set at $85 \%$ with a lag of $10 \mu \mathrm{sec}$. Unless noted, currents were leak-subtracted by the $\mathrm{P} / 4$ protocol, and data were analyzed using pClamp6.0 software. Conductance values were obtained by dividing the current by the electrochemical driving force $\left(I_{\mathrm{K}} /\left(V_{\mathrm{m}}-E_{\mathrm{k}}\right)\right)$. Normalized conductance-voltage plots were obtained by normalizing conductance $(G)$ to maximal conductance $\left(G_{\max }\right)$ and fit using the nonlinear leastsquares fit of a Boltzmann isoform $G=G_{\max } /\left[1+\exp \left(V-V_{1 / 2} / k\right)\right]$, where $V_{1 / 2}$ is the voltage at half-maximal activation, and $k$ is the slope factor. Although recordings were partially corrected for series resistance $(\sim 85 \%)$, no compensation for additional errors was performed. We estimate that residual uncorrected errors in the estimates of the shift in voltage dependence of activation should be minimal. In particular, this value is most affected by current detectable near the threshold of activation, where the calculated maximal error is $<1 \mathrm{mV}$. Conductances were normalized to those measured at a membrane potential of $+60 \mathrm{mV}$, which was designated as $V_{\max }$. Because Kv3.1 current is relatively nonsaturating even at very positive potentials, and the current density in our expression system is high, only those experiments in which the currents did not exceed the output of the amplifier at $+60 \mathrm{mV}$ were used in this analysis (Kanemasa et al., 1995).

Inactivation curves for Kv3.1-transfected $\mathrm{CHO}$ cells were obtained by a $200 \mathrm{msec}$ test pulse to $40 \mathrm{mV}$, preceded by $30 \mathrm{sec}$ prepulses ranging from -80 to $+20 \mathrm{mV}$ in $20 \mathrm{mV}$ increments. The holding potential was kept at $-80 \mathrm{mV}$. Data were fit using the Boltzmann isotherm. To ensure full recovery of inactivated currents between trials, the cells were given a $1 \mathrm{~min}$ recovery period at $-80 \mathrm{mV}$. Average data are expressed as means \pm SE. It should, however, be noted that because a 2 min prepulse potential at $-40 \mathrm{mV}$ was used to exclusively study the native highthreshold component of outward K current in MNTB neurons, we also conducted preliminary experiments in $\mathrm{CHO}$ cells after phosphatase treatment using a $2 \mathrm{~min}$ prepulse at $-40 \mathrm{mV}$. After a prepulse potential to $-40 \mathrm{mV}$ for $2 \mathrm{~min}$, channels were inactivated in excess of 50 when current was evoked at a test potential of $+20 \mathrm{mV}$.

Phorbol 12-myristate 13-acetate (PMA), 1-[5-isoquinolinesulfonyl]-2methyl piperazine (H-7), $N$-(2-aminoethyl)-5-chloronaphthalene-1-sulfonamide- $\mathrm{HCl}(\mathrm{A} 3)$, and 5,6-dichloro-1- $\beta$-D-ribof uranosylbenzimidazole (DRB) were obtained from Calbiochem (San Diego, CA).

Preparation of brainstem slices. Brains were rapidly removed from postnatal 9- to 14-d-old rats, after decapitation and placed into ice-cold bicarbonate-buffered artificial CSF (ACSF) (in mM: $125 \mathrm{NaCl}, 2.5 \mathrm{KCl}$, $26 \mathrm{NaHCO}_{3}, 1.25 \mathrm{NaH}_{2} \mathrm{PO}_{4}, 2 \mathrm{Na}$ pyruvate, 3 myo-inositol, 10 glucose, 2 $\mathrm{CaCl}_{2}$, and $1 \mathrm{MgCl}_{2}, \mathrm{pH}$ 7.4) solution gassed with $95 \% \mathrm{O}_{2}$ and $5 \% \mathrm{CO}_{2}$. The area of the brainstem containing MNTB nuclei was cut into four to six transverse slices using a vibrotome. The slices were incubated at $37^{\circ} \mathrm{C}$ for $1 \mathrm{hr}$ and thereafter kept at room temperature $\left(22-25^{\circ} \mathrm{C}\right)$.

Electrophysiological recordings from MNTB. One slice was transferred to a recording chamber mounted on an Olympus microscope fitted with Nomarski optics and a $60 \times$ water immersion objective. The chamber was continually perfused $(1 \mathrm{ml} / \mathrm{min})$ with gassed ACSF. Whole-cell voltage clamp recordings were made from visually identified MNTB neurons as described in CHO cells. Current-clamp experiments were conducted using an Axopatch 2D amplifier. Intracellular solution contained $32.5 \mathrm{~mm}$ $\mathrm{KCl}$, 97.5 K-gluconate, $5 \mathrm{~mm}$ EGTA, $10 \mathrm{~mm} \mathrm{HEPES}$, and $1 \mathrm{~mm} \mathrm{MgCl}_{2}$, $\mathrm{pH}$ 7.2. The extracellular calcium concentration was lowered to $0.5 \mathrm{~mm}$ to minimize the contribution of calcium-activated $\mathrm{K}$ channels, and TTX $(0.5 \mu \mathrm{M})$ was included in the ACSF to block sodium currents. The mean cell capacitance was $12.0 \pm 0.4 \mathrm{pF}$ with a mean series resistance of $5.3 \pm$ $0.4 \mathrm{M} \Omega$. Total current was compared before and after addition of activators of PKC in the presence and absence of PKC inhibitors. Averaged data are expressed as means \pm SE. Conductance and normalized conductance values were obtained as described above.
Metabolic labeling and immunoprecipitation. Stably transfected $\mathrm{CHO}$ cells expressing Kv3.1 or untransfected cells were grown to $80 \%$ confluence. Cells were preincubated with methionine-deficient DMEM (Life Technologies) plus 25 mM HEPES for 30 min, which was replaced with fresh media supplemented with $100 \mu \mathrm{Ci} / \mathrm{ml}$ of $\left[{ }^{35} \mathrm{~S}\right] \mathrm{me}-$ thionine (Amersham, Arlington Heights, IL). Medium was removed, and cells were washed three times with ice-cold PBS. Cells were lysed with RIPA buffer $(150 \mathrm{~mm} \mathrm{NaCl}, 1.0 \%$ Nonidet P-40, $0.5 \%$ deoxycholate, $0.1 \%$ SDS, and $50 \mathrm{~mm}$ Tris, $\mathrm{pH} 8.0$ ) containing a protease inhibitor cocktail (Boehringer Mannheim) and phosphatase inhibitors $(100 \mu \mathrm{M} \mathrm{NaF}$ and $0.2 \mathrm{~mm} \mathrm{NaVO}$ ), and allowed to incubate on a rocking platform for $30 \mathrm{~min}$ at $4^{\circ} \mathrm{C}$. Lysates were spun in a microf uge for $15 \mathrm{~min}$, and the supernatant was transferred to a new tube. Lysates were precleared with a $50 \%$ slurry aliquot of protein A Sepharose beads (Pharmacia Biotech, Piscataway, NJ), followed by incubation with a specific anti-Kv3.1 antibody at 1:1000 dilution, $4^{\circ} \mathrm{C}$, overnight (Perney and Kaczmarek, 1997). Lysates were immunoprecipitated with protein A Sepharose beads for $2 \mathrm{hr}$ at $4^{\circ} \mathrm{C}$, spun, and washed three times in Triton X-100 buffer $(0.1 \%$ Triton X-100, $0.1 \%$ SDS, $300 \mathrm{~mm}$ $\mathrm{NaCl}$, and $50 \mathrm{~mm}$ Tris, $\mathrm{pH}$ 7.5). For those samples treated with alkaline phosphatase, beads were resuspended in $50 \mu \mathrm{l}$ of phosphatase buffer (50 mu Tris- $\mathrm{HCl}, \mathrm{pH} 8.0,5 \mathrm{~mm} \mathrm{MgCl} 2,100 \mathrm{~mm} \mathrm{NaCl}$, and $5 \%$ glycerol), and the reaction was initiated by the addition of $5 \mathrm{U} / \mu \mathrm{l}$ phosphatase. Samples were incubated for $1 \mathrm{hr}$ at $37^{\circ} \mathrm{C}$, followed by three washes with Triton X-100 buffer. All samples were eluted by boiling in $1 \times$ SDS-PAGE sample buffer $(62.5 \mathrm{~mm}$ Tris, $\mathrm{pH} 6.8,4 \%$ SDS, $10 \%$ glycerol, $0.02 \%$ bromophenol blue, and $4 \% \beta$-mercaptoethanol) for $5 \mathrm{~min}$. Samples were subjected to SDS-PAGE on a $7.5 \%$ gel. The gel was fixed with $10 \%$ acetic acid and $50 \%$ methanol for $1 \mathrm{hr}$, washed, and soaked in Amplify (Amersham). The gel was dried, and labeled peptides were visualized by fluorography.

For ${ }^{32} \mathrm{P}$ metabolic labeling, stably transfected $\mathrm{CHO}$ cells expressing Kv3.1 were labeled metabolically with $\left[{ }^{32} \mathrm{P}\right]$ orthophosphate. Stably transfected $\mathrm{CHO}$ cells were grown to $70-80 \%$ confluence in Iscove's media. Cells were preincubated with phosphate-deficient DMEM (Life Technologies) plus $25 \mathrm{~mm}$ HEPES for $30 \mathrm{~min}$, which was replaced with fresh media supplemented with $500 \mu \mathrm{Ci} / \mathrm{ml}$ of carrier-free $\left[{ }^{32} \mathrm{P}\right]$ orthophosphate (Amersham) and allowed to incubate to equilibrium. Cells were then subjected to agonist stimulation for 15 min, medium was removed, and cells were washed three times with ice-cold PBS. Cells were lysed, immunoprecipitated, and subjected to SDS-PAGE as described above. Immunoprecipitates treated with alkaline phosphatase were performed as described above. The gel was fixed as above, dried, and bands were visualized by autoradiography.

Phosphoamino analysis. Stably transfected $\mathrm{CHO}$ cells expressing Kv3.1 were labeled metabolically with $\left[{ }^{32} \mathrm{P}\right]$ orthophosphate. Lysates were prepared, immunoprecipitated, and electrophoresed as above. The gel was transferred to a polyvinylidene difluoride (PVDF) membrane, and the Kv3.1 protein band was visualized by autoradiography. The bands corresponding to Kv3.1 were excised, rehydrated with methanol, and hydrolyzed with $6 \mathrm{~N} \mathrm{HCl}$ for $1 \mathrm{hr}$ at $110^{\circ} \mathrm{C}$. The samples were spun in a microfuge, decanted, and lyophilized. The lyophilized sample was resuspended in $10 \mu \mathrm{l}$ of $\mathrm{pH} 1.9$ buffer $(2.5 \%$ formic acid and $7.8 \%$ acetic acid) containing $5 \mathrm{~mm}$ each of phosphoamino acid standards. The sample was spotted $1.5 \mathrm{~cm}$ from the edge of a $10 \times 10$ $\mathrm{cm}$ cellulose TLC plate (Macalaster Bicknell, New Haven, CT) and analyzed by two-dimensional high-voltage electrophoresis. The sample was run in the first dimension for $45 \mathrm{~min}$ at $1000 \mathrm{~V}$. The plate was dried and re-wet with $\mathrm{pH} 3.5$ buffer ( $0.5 \%$ pyridine and $5.0 \%$ acetic acid) and run in the second dimension for $15 \mathrm{~min}$ at $1000 \mathrm{~V}$. The plate was dried, and standards were visualized by ninhydrin ( $0.2 \%$ solution in acetone) for $5 \mathrm{~min}$ in an $80^{\circ} \mathrm{C}$ oven. The sample phosphoamino acids were visualized by autoradiography.

\section{RESULTS}

\section{Kv3.1 is constitutively phosphorylated}

Kv3.1 has 11 putative PKC phosphorylation sites and 10 putative CK2 sites. The direct incorporation of phosphate into the Kv3.1 channel protein has not been demonstrated, although the amplitude of Kv3.1 current has been shown to decrease in response to activators of PKC in several heterologous expression systems (Critz et al., 1993; Kanemasa et al., 1995). We therefore examined phosphorylation of Kv3.1 expressed in 


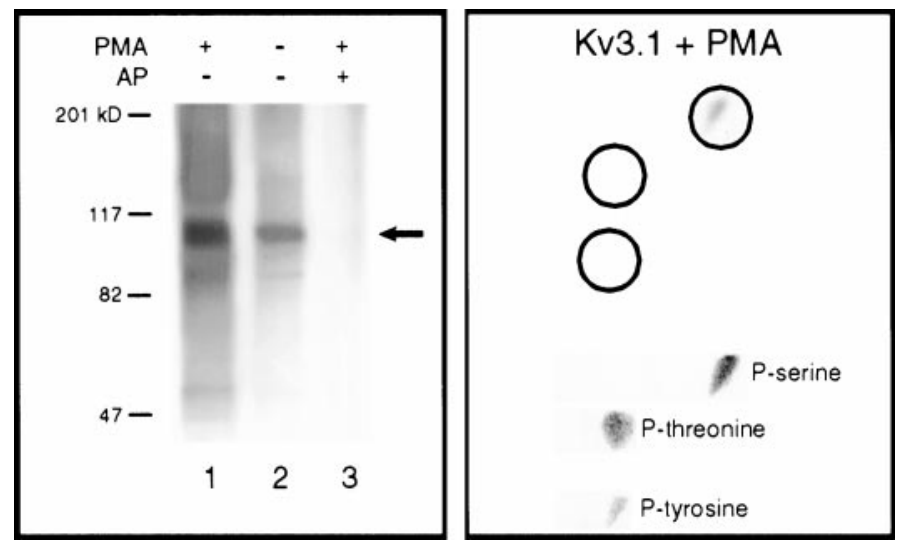

Figure 1. In vivo phosphorylation of $\mathrm{Kv} 3.1$ in $\mathrm{CHO}$ cells. $\mathrm{CHO}$ cells expressing Kv3.1 were radiolabeled with $\left[{ }^{32} \mathrm{P}\right]$ orthophosphate to equilibrium, stimulated with or without $100 \mathrm{nM}$ PMA for $15 \mathrm{~min}$, and lysed. Lysates were immunoprecipitated with anti-Kv3.1 antibody (lanes 1, 2). An additional ${ }^{32} \mathrm{P}$-labeled Kv3.1 sample was subjected treatment of the immunoprecipitated phosphoprotein with calf intestinal alkaline phosphatase $(A P)$ for $1 \mathrm{hr}$ at $37^{\circ} \mathrm{C}$ (lane 3 ). Samples were run on a $7 \%$ SDS-PAGE gel, and samples were visualized by autoradiography (right panel). Mobility of molecular weight markers is shown on left. Phosphoamino acid analysis of the Kv3.1 channel protein. Lysates were prepared, immunoprecipitated, and electrophoresed as above. The gel was transferred to a PVDF membrane, and the Kv3.1 protein band was visualized by autoradiography. The bands corresponding to Kv3.1 were excised, rehydrated with methanol, and hydrolyzed with $6 \mathrm{~N} \mathrm{HCl}$ for 1 $\mathrm{hr}$ at $110^{\circ} \mathrm{C}$. Labeled phosphoamino acids were resolved by twodimensional thin layer, the plate was dried, and standards were visualized by ninhydrin staining and sample phosphoamino acids were visualized by autoradiography.

$\mathrm{CHO}$ cells in both the presence and absence of the phorbol ester activator of PKC, PMA. Cells stably expressing the channel protein were radiolabeled to equilibrium with $\left[{ }^{32} \mathrm{P}\right]$ orthophosphate and then stimulated for 15 min with 100 nM PMA or vehicle alone. Immunoprecipitation of Kv3.1 revealed incorporation of ${ }^{32} \mathrm{P}$ into the Kv3.1 protein, which has a molecular mass of $\sim 110 \mathrm{kDa}$ in both stimulated and unstimulated cells (Fig. 1, left panel, lanes 1 and 2, respectively). Immunoprecipitation also yielded an additional band corresponding to the predicted molecular weight of the unglycosylated form of the channel protein $(80 \mathrm{kDa})$, which is the size of $\mathrm{Kv} 3.1$ when it is translated in vitro in the absence of membranes (data not shown). Incorporation of ${ }^{32} \mathrm{P}$ into the Kv3.1 channel protein could be completely reversed by treatment of the immunoprecipitated phosphoprotein with calf intestinal alkaline phosphatase (Fig. 1, left panel, lane 3).

Of the 21 consensus phosphorylation sites for CK2 and PKC in Kv3.1, 9 are serine, and 12 are threonine. We determined the incorporation of phosphate into specific amino acids by immunoprecipitating Kv3.1 from PMA-stimulated $\mathrm{CHO}$ cells radiolabeled with $\left[{ }^{32} \mathrm{P}\right]$ orthophosphate. Immunoprecipitates were then subjected to phosphoamino acid analysis. Radioactivity comigrating with unlabeled phosphoserine, but not phosphothreonine or phosphotyrosine, was detected after acid hydrolysis of ${ }^{32} \mathrm{P}$ labeled Kv3.1 (Fig. 1, right panel). Similar results were obtained in $\mathrm{CHO}$ cells that were not stimulated with PMA (data not shown). These results indicate that, of the putative consensus sites for PKC- and CK2-mediated phosphorylation, only those containing serine residues are phosphorylated.
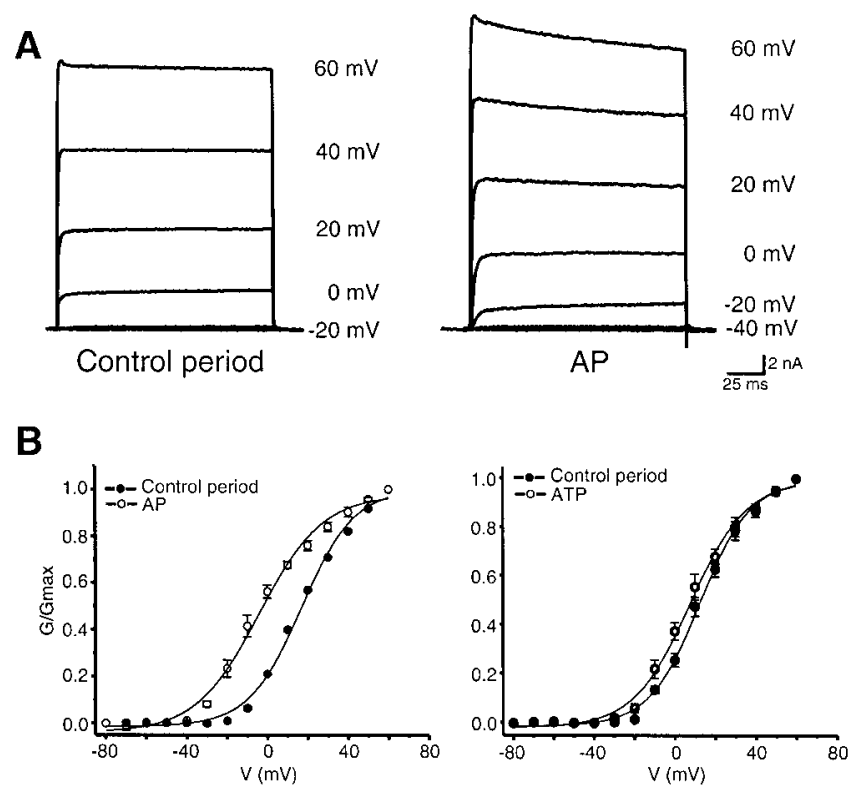

Figure 2. A, Current-voltage relationship for Kv3.1 currents recorded from $\mathrm{CHO}$ cells in the whole-cell configuration during the control period of AP treatment $(5 \mathrm{U} / \mathrm{ml})$ and 30 min after dialysis in the intracellular solution. Currents were evoked by depolarizing the membrane from a holding potential of $-80 \mathrm{mV}$ to test potentials from -80 to $+60 \mathrm{mV}$ in 10 $\mathrm{mV}$ increments, with $20 \mathrm{mV}$ increments shown for raw currents. $B$, Conductance values were obtained by dividing current by the electrochemical driving force $\left(I_{\mathrm{K}} /\left(V_{\mathrm{m}}-E_{\mathrm{k}}\right)\right)$. Normalized conductance-voltage plots were obtained by normalizing conductance $(G)$ to maximal conductance $\left(G_{\max }\right)$ and fit using the nonlinear least-squares fit of a Boltzmann isoform. Summary of normalized conductance-voltage relationship for Kv3.1 comparing the control period at $t=0 \mathrm{~min}$ to $30 \mathrm{~min}$ phosphatase treatment (left) or ATP (right).

\section{Dephosphorylation shifts the voltage dependence of activation of Kv3.1 in transfected cells}

To determine the role of basal phosphorylation of the Kv3.1 protein on its electrical properties, we performed whole-cell patch clamp recording in which phosphatase was included in the intracellular solution over a $30 \mathrm{~min}$ recording period. A timedependent increase in macroscopic current was observed in response to alkaline phosphatase $(n=8$; Fig. $2 A)$. In control recordings (+ATP) without phosphatase, very little change in current amplitude occurred over the same time period (see below). The increase in whole-cell conductance was significantly greater at negative potentials, and the threshold of activation was shifted to more negative potentials $(-40 \mathrm{mV})$ in all experiments conducted. Thus, currents could be evoked at potentials in which no current is detectable in control recordings. When the normalized conductance was plotted as a function of membrane potential, the voltage dependence of activation was found to be shifted to negative potentials after dialysis with phosphatase. Curves were well fit by a single Boltzmann isotherm (Fig. $2 B$, left). The half-activation potential $\left(V_{1 / 2} \max \right)$ for the control period was $16.9 \pm 1.3 \mathrm{mV}(k=13.1 \pm 1.1)$ versus $-3.92 \pm 1.63 \mathrm{mV}(k=$ $15.4 \pm 1.6)$ after $30 \mathrm{~min}$ dialysis with phosphatase, resulting in a total leftward shift of over $20 \mathrm{mV}$ in the voltage dependence of activation $(n=4)$.

To eliminate the possibility that the shift in voltage dependence was attributable to washout of intracellular anions, as has been reported for other channels when recorded in the whole-cell configuration (Fenwick et al., 1982; Oliva et al., 1988), we dia- 
A

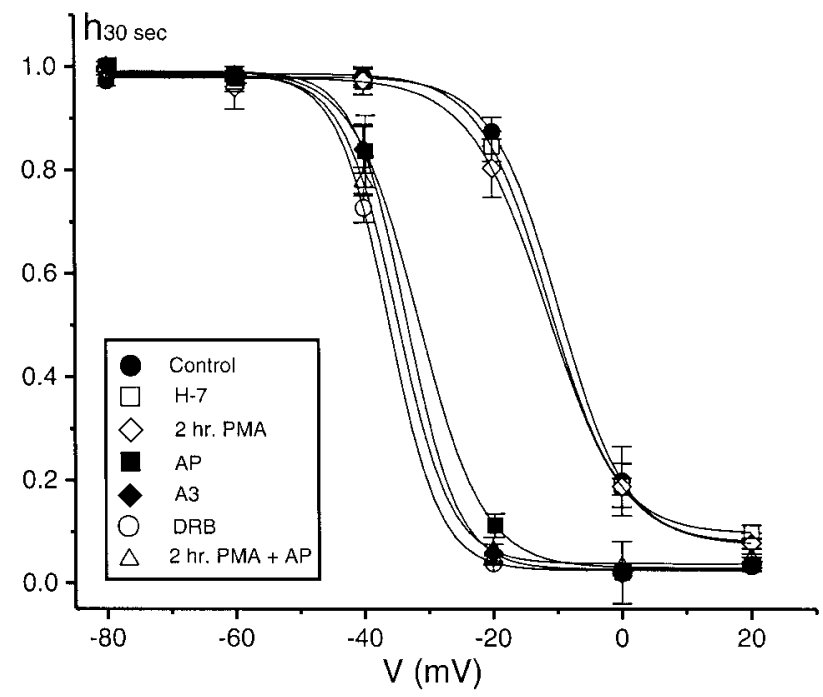

B

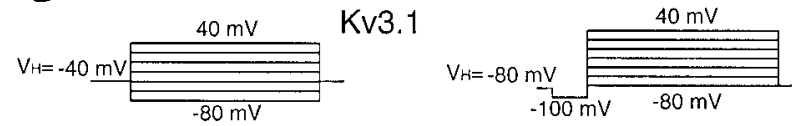

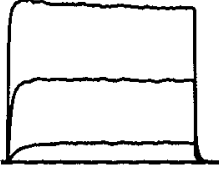

IV 40 Control period

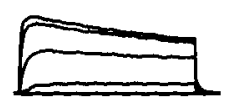

IV40 AP

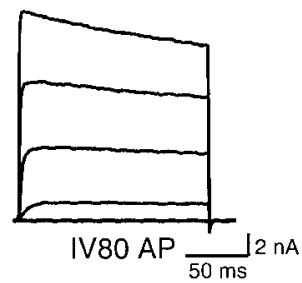

Figure 3. Steady-state inactivation $\left(h_{30 \mathrm{sec}}\right)$ of Kv3.1. $A$, Steady-state inactivation of Kv3.1 was determined by holding the membrane potential from a prepulse potential ranging from -80 to $20 \mathrm{mV}$ for $30 \mathrm{sec}$ to a test pulse of $40 \mathrm{mV}$ for $150 \mathrm{msec}$, with a $1 \mathrm{~min}$ period between each prepulse. Current amplitude was normalized to the maximum current, and the inactivation curve was fit using the nonlinear least-squares fit of a Boltzmann isoform. Treatment and absolute $V_{1 / 2}$ values are summarized in Table 1. B, Left, Evoked current from a holding potential of $-40 \mathrm{mV}$ for 2 min to test potentials from $-80 \mathrm{mV}$ to $+40 \mathrm{mV}$ in $20 \mathrm{mV}$ increments during control period and after AP treatment; right, recovery of current from inactivation by stepping from a holding potential of $-80 \mathrm{mV}$ in 20 $\mathrm{mV}$ increments from $-80 \mathrm{mV}$ to $+40 \mathrm{mV}$.

lyzed Kv3.1-transfected $\mathrm{CHO}$ cells with intracellular solution without alkaline phosphatase (AP), but containing $1 \mathrm{mM}$ ATP to minimize shifts in voltage dependence associated with dephosphorylation. Only a small change in whole-cell conductance and shift in voltage dependence of activation was observed under these conditions (Fig. $2 B$, right; $n=6$ ). The potential at which $\mathrm{Kv} 3.1$ is half activated during the control period was $12.5 \pm 0.98$ $\mathrm{mV}(k=12.6 \pm 0.87 \mathrm{mV})$ and was $7.7 \pm 1.10 \mathrm{mV}(k=14.0 \pm 1.09$ $\mathrm{mV}$ ) after $30 \mathrm{~min}$ dialysis.

\section{Dephosphorylation shifts the voltage dependence of inactivation of Kv3.1 in transfected cells}

To determine whether the inactivation characteristics of Kv3.1 were also affected by dephosphorylation, we used a two-pulse protocol to measure voltage dependence of inactivation. A $30 \mathrm{sec}$ prepulse to potentials between -80 and $20 \mathrm{mV}$ allowed inactivation to develop, and this was followed by a test pulse to $40 \mathrm{mV}$. In the absence of exogenous phosphatase (ATP alone), the potential at which Kv3.1 is half inactivated $\left(\mathrm{V}_{1 / 2}\right)$ is $-9.65 \mathrm{mV}$ (Fig. 3, filled
Table 1. Effect of inhibitors on voltage dependence of inactivation

\begin{tabular}{llll} 
Sample & $V_{1 / 2}(\mathrm{mV})$ & $k(\mathrm{mV})$ & $n$ \\
\hline Control (ATP) & $-9.7 \pm 0.3$ & $5.1 \pm 0.2$ & 5 \\
${\mathrm{H}-7^{a}}^{a}$ & $-11.2 \pm 0.7$ & $5.3 \pm 0.3$ & 5 \\
$2 \mathrm{hr} / \mathrm{PMA}^{a}$ & $-11.5 \pm 0.8$ & $5.9 \pm 0.5$ & 6 \\
$\mathrm{AP}$ & $-31.8 \pm 0.1$ & $5.0 \pm 0.3$ & 5 \\
$\mathrm{A3}^{b}$ & $-33.3 \pm 0.8$ & $4.0 \pm 0.4$ & 3 \\
$\mathrm{DRB}^{b}$ & $-36.1 \pm 1.1$ & $3.9 \pm 1.0$ & 5 \\
$2 \mathrm{hr} . \mathrm{PMA}+\mathrm{AP}$ & $-34.8 \pm 1.0$ & $4.1 \pm 0.7$ & 3 \\
\hline
\end{tabular}

${ }^{a}$ PKC inhibitor.

${ }^{b} \mathrm{CKII}$ inhibitor.

circles). Alkaline phosphatase produced a $20 \mathrm{mV}$ leftward shift in the inactivation curve to a midpoint potential of inactivation of $-31.8 \mathrm{mV}$ (Fig. 3, filled squares). These data are summarized in Table 1. Dialysis of CHO cells for $30 \mathrm{~min}$ in the presence of ATP did not produce the significant shifts in voltage dependence of inactivation that were observed with AP treatment, producing only modest shifts of $V_{1 / 2}$ to $-16.7 \pm 2.1 \mathrm{mV}(n=10)$.

Because the voltage dependence of inactivation was shifted to more negative potentials, we determined the effect on Kv3.1 current by holding the membrane at $-40 \mathrm{mV}$ for $2 \mathrm{~min}$, in anticipation of experiments conducted in native MNTB neurons (see below). Based on our findings in Figure $3 A$, we predicted that we would see a loss of evoked currents caused by an increase in the number of channels in the inactivated state. Indeed, from a holding potential of $-40 \mathrm{mV}$ in $\mathrm{CHO}$ cells expressing Kv3.1, an apparent saturation of current was observed after alkaline phosphatase treatment (Fig. 3B, left panel). The onset of steady-state inactivation was slow; stepping from a holding potential of -40 $\mathrm{mV}$ for a period ranging from 0 to 2 min resulted in an incremental decrease in outward current in response to subsequent depolarizations (data not shown). Full recovery from the inactivated state resulted when current was again evoked from a holding potential of $-80 \mathrm{mV}$ (Fig. $3 B$, right panel).

\section{Dephosphorylation of native Kv3.1 current in MNTB neurons affects its voltage dependence}

To determine whether the effect of alkaline phosphatase on Kv3.1 in transfected CHO cells is preserved in MNTB neurons, we next tested the effect of phosphatase using the whole-cell configuration in brainstem slices. In MNTB neurons, the high-threshold Kv3.1 current can be discriminated from a smaller, low-threshold outward current by holding the membrane potential at $-40 \mathrm{mV}$ for 2 min, a potential at which the low-threshold, TEA-insensitive component of the outward current is fully inactivated. The highthreshold component, corresponding to $\mathrm{Kv} 3.1$, accounts for $>80 \%$ of total outward current in MNTB neurons (Wang et al., 1998a). As previously reported in MNTB neurons, stepping from a holding potential of $-40 \mathrm{mV}$ to test potentials of -80 to +40 $\mathrm{mV}$ in $20 \mathrm{mV}$ steps, revealed large, outward, noninactivating currents, with a threshold of activation of $-20 \mathrm{mV}$ (Brew and Forsythe, 1995; Wang et al., 1998a). Alkaline phosphatase produced an increase in holding current at $-40 \mathrm{mV}$ (Fig. $4 A, B$ ). The increase in holding current is consistent with a shift in the activation of Kv3.1 to more negative potentials in response to phosphatase. This current at $-40 \mathrm{mV}$ after phosphatase treatment was significantly blocked by $1 \mathrm{~mm}$ TEA (Fig. 4A,C), a concentration that blocks only the Kv3.1 current but does not affect the low-threshold outward currents in MNTB neurons 

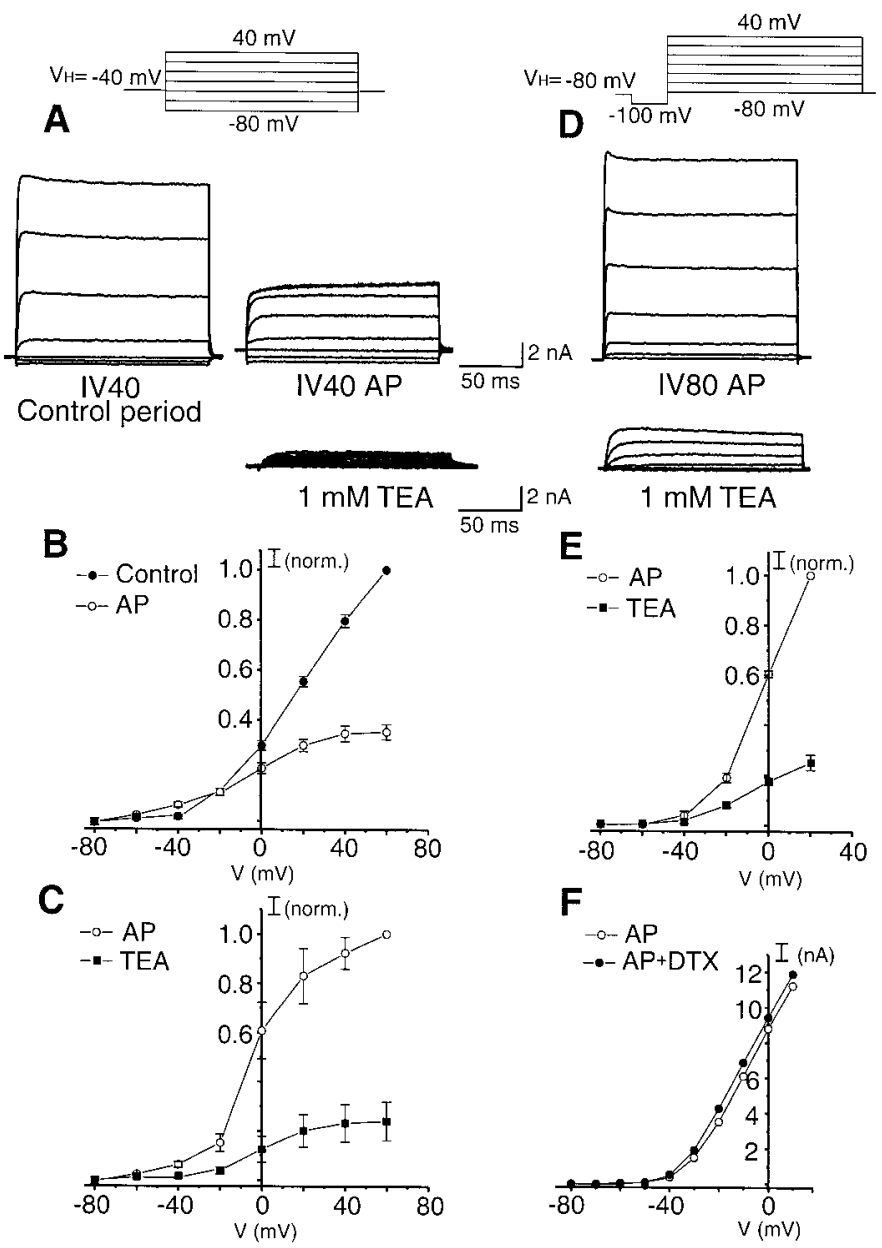

Figure 4. AP shifts the voltage dependence of activation and inactivation in MNTB neurons. To discriminate the high-threshold TEA-sensitive current from total outward current, the membrane potential was held at $-40 \mathrm{mV}$ for $2 \mathrm{~min}$; currents were evoked by stepping from a holding potential of -40 to $+40 \mathrm{mV}$ in $20 \mathrm{mV}$ increments taken at the beginning of dialysis of phosphatase $(t=0)$ and at $t=15 \mathrm{~min}$. A, Top, Reduction of current amplitude after AP treatment, leak subtraction was disabled to discriminate any changes in the current that may occur at more negative potentials; bottom, inhibition of current by 1 mM TEA. $B$, Summary of normalized high-threshold current during control period and 15 min after phosphatase treatment $(n=8)$. All values are mean \pm SEM. $C$, Summary of normalized data of the effect of $1 \mathrm{~mm}$ TEA on current after AP treatment $(n=8)$. $D$, Recording from same neuron in $A$ showing recovery of outward current when current was evoked by stepping from a holding potential of -80 to $+40 \mathrm{mV}$ in $20 \mathrm{mV}$ increments during the control period and after phosphatase treatment. $E$, Summary of normalized data of TEA-sensitive component of outward current after phosphatase treatment, normalized to current after AP treatment $(n=7)$. All data are normalized to $+20 \mathrm{mV}$ so data from all experiments could be included, i.e., those experiments in which current exceeded the output of the amplifier at +40 to $+60 \mathrm{mV}$. F, Current-voltage relationship of total outward current after phosphatase treatment and after $7 \mathrm{~min}$ perfusion of $100 \mathrm{~nm}$ DTX into the bath from a holding potential of $-80 \mathrm{mV}$.

(Wang et al., 1998a). Treatment with alkaline phosphatase also produced a rapid reduction in the high-threshold current that was maximal by $15-20 \mathrm{~min}$ of dialysis with the phosphatase (Fig. $4 A$, right trace). A reduction of current from a holding potential of $-40 \mathrm{mV}$ was expected because of the shift in the voltage dependence of inactivation to more negative potentials in response to alkaline phosphatase, consistent with the findings in Figure 3.

As seen in CHO cells expressing Kv3.1 (Fig. 3B), total outward current evoked by stepping from a holding potential of $-80 \mathrm{mV}$ resulted in full recovery from inactivation. Figure $4 D$ shows a recording resulting from the same cell as shown in the Figure $4 A$. Under these recording conditions, most of the outward current evoked by stepping from $-80 \mathrm{mV}$ could be blocked by $1 \mathrm{~mm}$ TEA, indicating that it is likely to correspond to the native Kv3.1 channel (Fig. 4D,E). In addition, current evoked by stepping to $-40 \mathrm{mV}$ from a holding potential of $-80 \mathrm{mV}$ was blocked by 1 mM TEA, suggesting that most of the low-threshold current that is normally evoked by stepping from a holding potential of -80 $\mathrm{mV}$ in MNTB neurons runs down in response to phosphatase treatment (or to lack of ATP). To test this possibility, $100 \mathrm{~nm}$ dendrodotoxin (DTX) was perfused into the bath after treatment with phosphatase $(n=3)$, a concentration that blocks the lowthreshold component of outward current in MNTB neurons (Brew and Forsythe, 1995; Wang et al., 1998a) but has no effect on Kv3.1 channels (Grissmer et al., 1994; Brew and Forsythe, 1995). DTX had little or no effect on the amplitude of total outward current (Fig. 4F). This suggests that most of the remaining current after phosphatase treatment (including current at -40 $\mathrm{mV}$; Fig. 4B,E) is almost entirely Kv3.1-like current and that the TEA-resistant low-threshold component of total outward current runs down after phosphatase treatment. Finally, treatment with boiled alkaline phosphatase to destroy enzymatic activity had no effect on the high-threshold current evoked from a holding potential of $-40 \mathrm{mV}$ (data not shown).

\section{Protein kinase $\mathbf{C}$ is not responsible for the basal phosphorylation of Kv3.1}

As stated above, Kv3.1 has 4 putative serine PKC phosphorylation sites and 5 putative serine CK2 sites. We next attempted to identify the kinase responsible for the effect of basal phosphorylation of Kv3.1 by studying the impact of inhibitors of these two kinases on the voltage dependence of activation of Kv3.1 in CHO cells. To test the effect of PKC, cells were preincubated with the cell-permeable PKC inhibitor H-7 $(100 \mu \mathrm{M})$ for $30 \mathrm{~min}$ to $1 \mathrm{hr}$, and currents were measured. Inhibition of PKC using $\mathrm{H}-7$ had no effect on the voltage dependence of activation, as compared with control cells (control, $V_{1 / 2}=15.6 \pm 1.3, k=12.7 \pm 0.2 \mathrm{mV}, n=$ 14 ; H-7, $V_{1 / 2}=17.3 \pm 1.3 \mathrm{mV}, k=12.7 \pm 0.2 \mathrm{mV}, n=6$, respectively). In addition, preincubation with $\mathrm{H}-7$, followed by 30 min intracellular dialysis in the continued presence of $\mathrm{H}-7$, produced changes in current that were similar to those observed in control dialyzed cells (Fig. 5A, left panel, representative trace). Finally, when the holding potential was held at $-40 \mathrm{mV}, \mathrm{H}-7$ had little effect on total outward current (Fig. 5B, left panel).

Inhibition of $\mathrm{PKC}$ was also achieved by incubating $\mathrm{CHO}$ cells in the presence of $100 \mathrm{nM}$ PMA for $2 \mathrm{hr}$. We first measured membrane-associated PKC activity biochemically in response to 2 hr PMA treatment using histone IIIS as a substrate (data not shown). This assay revealed that PMA-mediated translocation in $\mathrm{CHO}$ cells was maximal by $15 \mathrm{~min}$, followed by a rapid downregulation of PKC activity. Under these conditions, we again found no shift in the voltage dependence of activation, and the midpoint of activation in the cells was $14.9 \pm 1.3 \mathrm{mV}, k=13.1 \pm$ $0.3 \mathrm{mV}, n=7$.

We also tested the effect of PKC inhibitors on inactivation of Kv3.1 using the two-pulse protocol. In the presence of $100 \mu \mathrm{M}$ $\mathrm{H}-7$, the midpoint potential of inactivation was similar to that of untreated control cells (Fig. 3, open squares; Table 1). After $2 \mathrm{hr}$ incubation with PMA, the $V_{1 / 2}$ of inactivation was also unaltered (Fig. 3, open diamonds; Table 1). In addition, in cells pretreated 


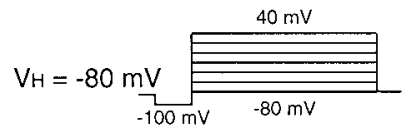

A

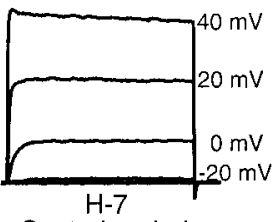

Control period
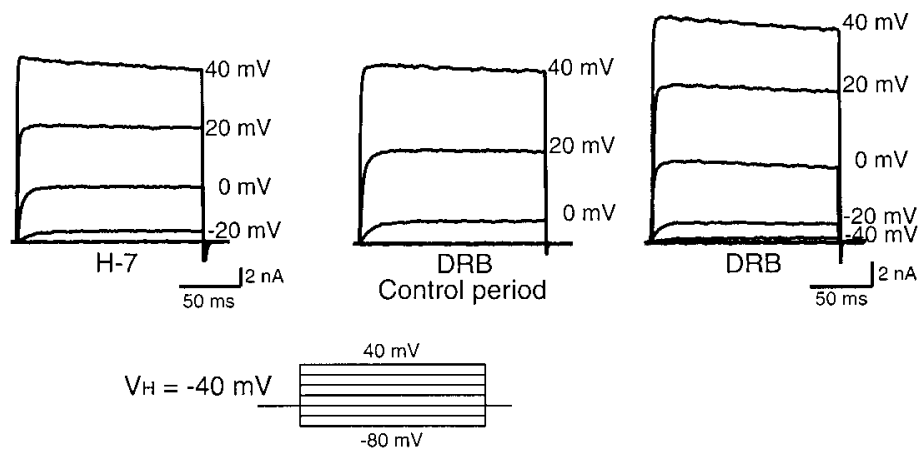

B

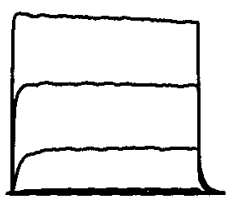

$\mathrm{H}-7$

Control period

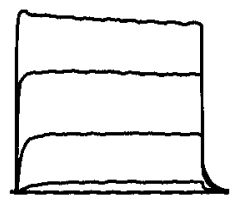

$\mathrm{H}-7$

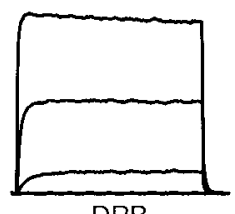

DRB

Control period

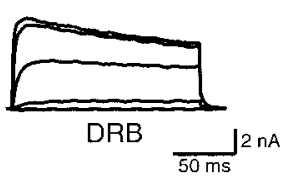

Figure 5. Effect of kinase inhibitors on Kv3.1 current in transected cells. A, Outward currents were evoked by stepping from a holding potential of -80 to $+40 \mathrm{mV}$ in 20 $\mathrm{mV}$ increments during the control period and after treatment with either $100 \mu \mathrm{M} \mathrm{H}-7$ or $20 \mu \mathrm{M}$ DRB. $B$, Outward currents evoked by holding from a membrane potential of $-40 \mathrm{mV}$ for $2 \mathrm{~min}$ to test potentials from -80 to $+40 \mathrm{mV}$ in $20 \mathrm{mV}$ increments during the control period and after treatment with either $100 \mu \mathrm{M} \mathrm{H}-7$ or $20 \mu \mathrm{M}$ DRB.
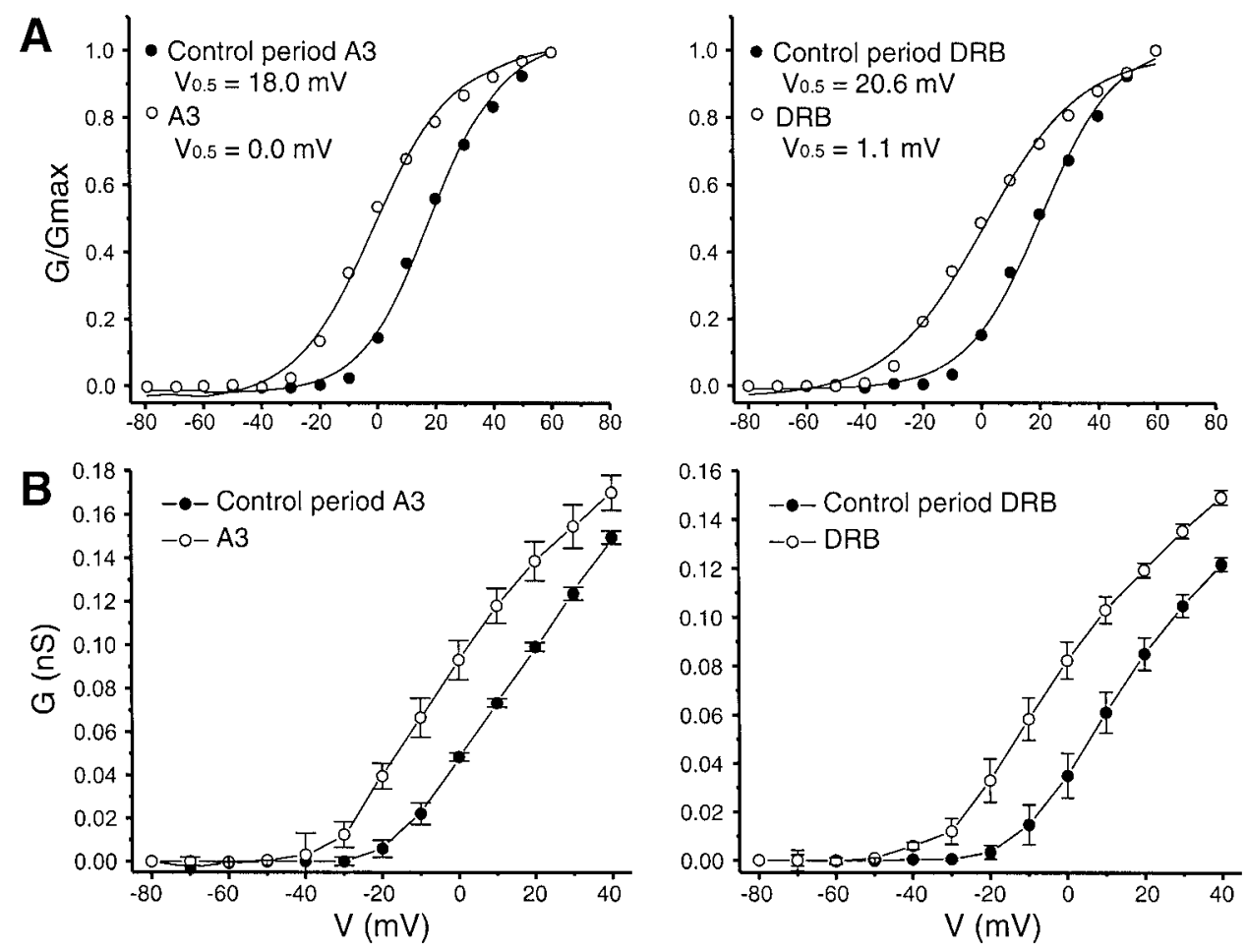

Figure 6. Steady-state activation of Kv3.1 after treatment with CK2 inhibitors. $A$, Normalized conductance-voltage relationship for Kv3.1 during control period and after treatment with either $20 \mu \mathrm{M} \mathrm{A} 3$ or DRB. Conductance values were obtained by dividing current by the electrochemical driving force $\left(I_{\mathrm{K}} /\left(V_{\mathrm{m}}-E_{\mathrm{k}}\right)\right)$. Normalized conductance-voltage plots were obtained by normalizing conductance $(G)$ to maximal conductance $\left(G_{\max }\right)$ and fit using the nonlinear least-squares fit of a Boltzmann isoform. $B$, Summary of conductance-voltage relationship of all experiments conducted with $\mathrm{A} 3$ or DRB.

with 2 hr PMA to downregulate PKC, dialysis of the cells with alkaline phosphatase resulted in a leftward shift in the voltage dependence of inactivation, confirming that a kinase other than PKC was responsible for the basal phosphorylation of Kv3.1 (Fig. 3 , open triangles; Table 1).

\section{Casein kinase 2 inhibitors mimic the effect of phosphatase on voltage dependence}

To test the involvement of CK2, cells were treated with either A3, a kinase inhibitor with inhibitory characteristics similar to H-7, with the exception of being additionally able to inhibit CK2, or with the selective CK2 inhibitor DRB (Zandomeni, 1989). Both of these agents produced changes similar to those observed in phosphatase-treated cells. Dialysis of $\mathrm{CHO}$ cells with intracellular solution containing $20 \mu \mathrm{M} \mathrm{A} 3$ for 30 min resulted in current detectable at potentials more negative than $-20 \mathrm{mV}$ in all experiments conducted, consistent with a change in the voltage dependence of activation (Fig. 6A,B, left panel). In addition, a similar shift in voltage dependence of activation was observed when $\mathrm{CHO}$ cells expressing Kv3.1 were dialyzed with the selective CK2 
inhibitor DRB $(20 \mu \mathrm{M})$. Figure 5, $A$ and $B$ (right panel), shows the typical effect of DRB on Kv3.1 current from holding potentials of -80 and $-40 \mathrm{mV}$, respectively. A normalized conductancevoltage curve is shown in Figure $6 A$ (right panel). A summary of the total data showing the effect of DRB on whole-cell conductance as a function of voltage is shown in Figure $6 B$ (right panel).

We also found that inhibitors of CK2 could mimic the effect of alkaline phosphatase on the voltage dependence. After 30 min A3 treatment, the midpoint potential of inactivation was comparable with that of phosphatase-treated cells, determined using the twopulse protocol described earlier (Fig. 3, closed triangles; Table 1). Similarly, after $30 \mathrm{~min}$ treatment with DRB, there was also a similar shift in the $V_{1 / 2}$ of inactivation (Fig. 3, open circles; Table 1).

In addition, we tested the capacity of GTP to serve as a phosphate donor because CK2 has the unique ability to use both ATP and GTP (Blanquet, 2000). As observed with ATP, dialysis of transfected cells with GTP as the phosphate donor resulted in only small shifts in the voltage dependence of inactivation from $-11.2 \pm 1.2 \mathrm{mV}(k=3.93)$ during the control period to $-19.6 \pm$ $2.4 \mathrm{mV}(k=4.27)$ after $30 \mathrm{~min}$ dialysis.

We next tested the effect of DRB on native currents of MNTB neurons. Like AP, DRB produced an increase in holding current at $-40 \mathrm{mV}$ (Fig. $7 A, B ; n=8$ ) again, consistent with a shift in the activation of Kv3.1 to more negative potentials in response to phosphatase. This current at $-40 \mathrm{mV}$ after DRB treatment was significantly blocked by $1 \mathrm{~mm}$ TEA (Fig. 7A,C). Like AP treatment, DRB also produced a rapid reduction in the high-threshold current (Fig. $7 A$, right trace). In addition, subsequently resetting the holding potential to $-80 \mathrm{mV}$ resulted in full recovery from inactivation (Fig. 7D). A majority of the outward current evoked by stepping from $-80 \mathrm{mV}$ could be blocked by $1 \mathrm{~mm}$ TEA, as expected for the native Kv3.1 channel (Fig. 4D,E).

Finally, to determine the effect of DRB on the firing properties of MNTB neurons, principal neurons were stimulated with brief current pulses at high frequencies ranging from 100 to $300 \mathrm{~Hz}$. During the control period of DRB dialysis, neurons were able to fire accurately at frequencies up to $300 \mathrm{~Hz}$ (Fig. 8A). After dialysis with DRB, neurons were able to fire at frequencies of 100 and $200 \mathrm{~Hz}$. However, at $300 \mathrm{~Hz}$, neurons failed to fire full action potentials after the first action potential (Fig. $8 B$ ). The effect of AP on these neurons was similar (a failure to fire at high frequencies). Because the effect of AP on the high-threshold current was very rapid, we were however, unable to obtain consistent control recordings from these neurons.

\section{DISCUSSION}

\section{CK2 inhibitors alter voltage dependence of Kv3.1}

CK2 is a ubiquitous second messenger-independent serine-threonine protein kinase consisting of two $\alpha$ catalytic and two regulatory $\beta$ subunits and is believed to be constitutively active. The regulatory $\beta$ subunit is also involved in targeting and plays a role in substrate specificity (Allende and Allende, 1995, 1998; Dobrowolska et al., 1999). CK2 has a wide variety of substrates, many of which are involved in cell cycle progression. Other substrates include those involved in protein synthesis, structural proteins, and signal transduction proteins (Allende and Allende, 1995). In addition, CK2 is emerging as an enzyme that plays a key role in neuronal tissue. The highest level of CK2 activity is in the brain and substrates have been identified in both synaptic and nuclear compartments (Blanquet, 2000). Moreover, CK2 has been shown to modulate NMDA channels in hippocampal neurons (Lieberman and Mody, 1999).

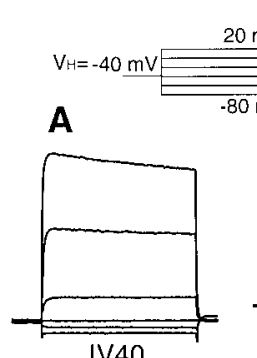

IV 40
Control period
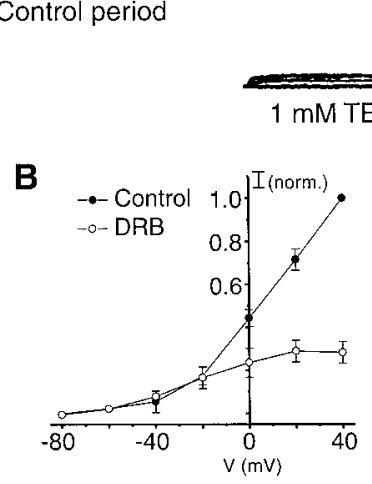

C

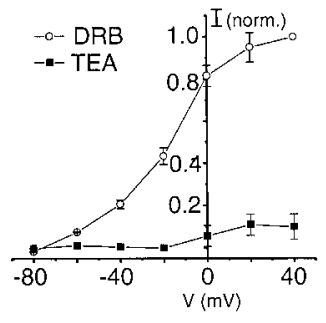

Figure 7. DRB shifts the voltage dependence of activation and inactivation in MNTB neurons, using the same protocol as in Figure 4. A, Top, Reduction of current amplitude after DRB treatment, leak subtraction was disabled to discriminate any changes in the current that may occur at more negative potentials; bottom, inhibition of current by $1 \mathrm{~mm}$ TEA. $B$, Summary of normalized high-threshold current during control period and $30 \mathrm{~min}$ after DRB treatment $(n=8)$. All values are mean $\pm \mathrm{SEM}$. $C$, Summary of normalized data of the effect of $1 \mathrm{mM}$ TEA on current after AP treatment $(n=8)$. $D$, Recording from same neuron in $A$ showing recovery of outward current when current was evoked by stepping from a holding potential of -80 to $+20 \mathrm{mV}$ in $20 \mathrm{mV}$ during the control period and after phosphatase treatment. E, Summary of normalized data of TEA-sensitive component of outward current after phosphatase treatment, normalized to current after AP treatment $(n=7)$.

The role of constitutive CK2-mediated phosphorylation of voltage-dependent ion channels has however, not been explored previously. Our findings indicate that a high level of constitutive phosphorylation of the Kv3.1 channel, consistent with CK2mediated phosphorylation, may profoundly influence the biophysical characteristics of the channel when expressed in $\mathrm{CHO}$ cells or in MNTB neurons. Inhibitors of CK2 mimic the effect of dephosphorylation by AP, although the effect of AP is more rapid than the effect of the kinase inhibitors. The slower effect of CK2 inhibitors likely reflects the rate of turnover of phosphorylation of the channel protein. DRB is thought to be a specific inhibitor of $\mathrm{CK} 2$, whereas $\mathrm{A} 3$ inhibits the same kinases as $\mathrm{H}-7$ but additionally inhibits CK2. Because $\mathrm{H}-7$ has little effect in comparison to $\mathrm{A} 3$, it is probable that the effect of $\mathrm{A} 3$ is attributable to inhibition of CK2. In addition to the use of inhibitors of CK2, we have shown that GTP, like ATP, may serve as a phosphate donor for the kinase responsible for constitutive phosphorylation of this 


\section{Control period DRB}
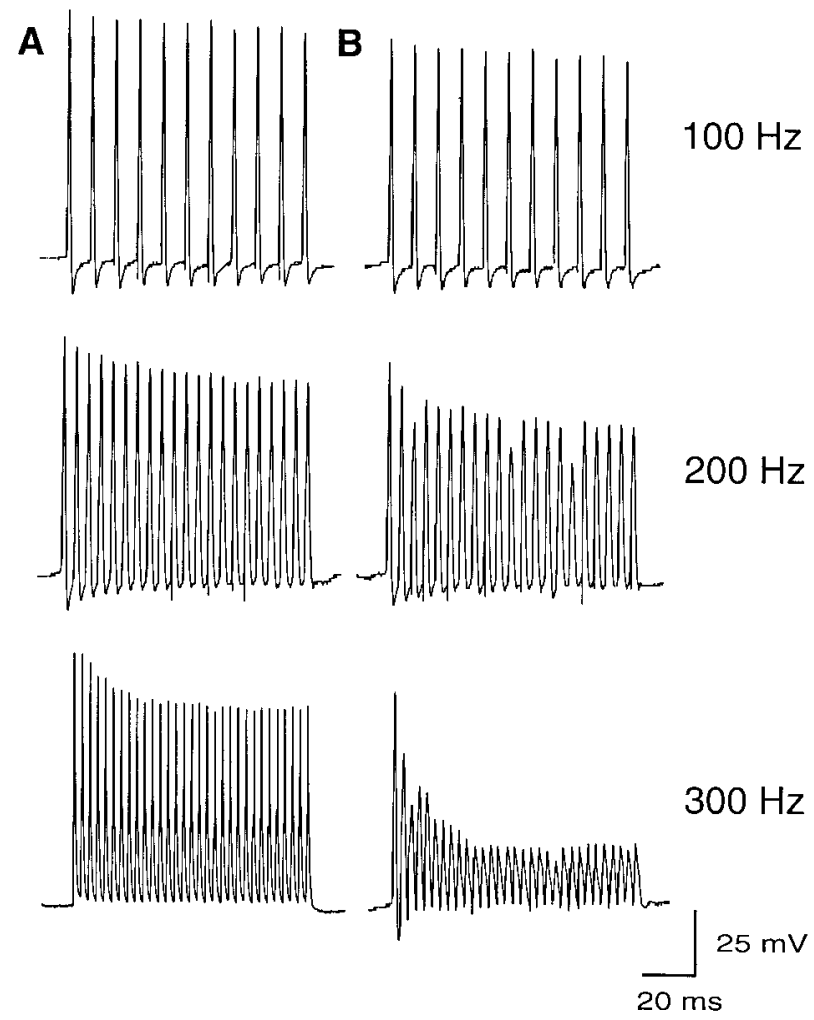

Figure 8. A, Representative recording from an MNTB neuron in response to brief current injections $(2 \mathrm{nA}, 0.3 \mathrm{msec})$ at three different test frequencies $(100-300 \mathrm{~Hz})$ during the control period of DRB dialysis in the intracellular recording solution. $B$, Recording from same neuron after 30 min dialysis with DRB.

channel. The large shifts in the voltage dependence associated with dephosphorylation of the channel were not observed in the presence of either ATP or GTP, being $\sim 6$ and $9 \mathrm{mV}$, respectively.

The properties of Kv3.1 that are sensitive to CK2, such as the their high-threshold of activation and inactivation, have been shown to be critical for the transmission of high-frequency signaling within the MNTB and are likely therefore to play a role in preserving auditory information (Brew and Forsythe, 1995; Wang et al., 1998a). In particular, the unique property of activation and inactivation at relatively positive potentials ensures that Kv3.1 has a minimal effect on the height of the action potential and is available to rapidly repolarize the membrane during highfrequency firing, as compared to other classic delayed rectifiers (Kanemasa et al., 1995; Wang et al., 1998a). Our finding that the ability of these neurons to fire at $300 \mathrm{~Hz}$ is impaired after DRB treatment and that the height of the action potential is significantly attenuated is consistent with a shift in the voltage dependence of the channel.

In contrast, our data indicate that PKC-mediated phosphorylation does not influence voltage dependence or kinetics of Kv3.1. However, PKC-mediated phosphorylation can acutely modulate Kv3.1 current amplitude, as has been previously demonstrated (Critz et al., 1993; Kanemasa et al., 1995).

\section{Possible mechanisms for effects of casein kinase} 2-mediated phosphorylation

Alkaline phosphatase and CK2 inhibitors produce effects on the voltage dependence of both activation and inactivation of Kv3.1, suggesting that phosphorylation contributes to both parameters. If inactivation occurs only from the open state, the shift in the voltage dependence of inactivation may occur simply as a result of the shift in the voltage dependence of activation. We attribute the saturation of current from a holding potential of $-40 \mathrm{mV}$ after phosphatase treatment to a cumulative inactivation. An accumulation of channels in the inactivated state from a holding potential of $-40 \mathrm{mV}$ would be predicted to occur as a result of the shift in the voltage dependence of inactivation to more negative potentials and to the short recovery period between pulses. It is however, also possible that the effects on the voltage dependence of activation and inactivation occur independently of each other. Although we cannot rule out the possibility that the effect of phosphatase treatment results from the dephosphorylation of an associated protein, our biochemical evidence that alkaline phosphatase eliminates phosphorylation of the immunoprecipitated Kv3.1 protein supports the hypothesis that the observed changes are attributable to direct dephosphorylation of the channel. Incorporation of a phosphate group into a channel protein may cause a conformational change in the protein or may alter its voltage sensitivity by an electrostatic interaction of the phosphate group with its voltage sensor (Perozo et al., 1989). The addition of the negative charge of the phosphate group at an internal site would be expected to shift the voltage dependence of the channel to more positive potentials, requiring additional depolarization to activate or inactivate the channel. It has been suggested that the incorporation of phosphate groups into the delayed-rectifier potassium channels of both the giant squid axon and of the constitutively phosphorylated neuronal potassium channel Kv2.1 modifies their sensitivity to depolarization by this electrostatic mechanism (Perozo and Bezanilla, 1990; Murakoshi et al., 1997). Phosphorylation of Kv2.1 has been shown to occur early in its biosynthesis, and dephosphorylation resulted in a shift in voltage dependence of activation of $>20 \mathrm{mV}$.

\section{Putative casein kinase 2 phosphorylation sites of Kv3.1}

From our data, we are unable to discriminate between individual CK2 phosphorylation sites, although it is conceivable that the effects of CK2 on activation and inactivation may involve more than one site. Potential CK2 phosphorylation sites in the Kv3.1 channel protein are found in both the $\mathrm{C}$ and $\mathrm{N}$ terminus, with the $\mathrm{C}$ terminus containing one serine site, and the $\mathrm{N}$ terminus containing two sites. A role for cytoplasmic domains in the modulation of activation and inactivation has been previously demonstrated in Kv2.1 (VanDonger et al., 1990). In addition, Kv3.1 has one putative CK2 site in the S5-S6 linker (the pore region) near the outer region of the pore, which is unlikely to be phosphorylated by a cytoplasmic kinase. Finally, Kv3.1 has a single putative CK2 phosphorylation site present in the intracellular S4/S5 linker, which is conserved in most voltage-dependent potassium currents, including the mammalian Shaw-like channels. A role for the S4-S5 linker in both the voltage dependence of activation and inactivation has been previously demonstrated in members of the Shaker and Shaw potassium channel subfamilies (Isakoff et al., 1991; McCormack et al., 1991; Rettig et al., 1992), and the putative CK2 site in the S4-S5 linker is conserved in most voltage-dependent $\mathrm{K}$ channels. Phosphorylation of this residue may influence the apparent voltage-transducing properties of the S4-S5 linker, leading to the observed alterations in voltage dependence of activation and/or inactivation in Kv3.1. Future studies aimed at identifying the sites responsible for the impact of dephosphorylation on the biophysical properties of Kv3.1 will 
provide further insight into the potential contribution of CK2 on ion channels properties.

\section{Can constitutively phosphorylated Kv3.1 be modulated by phosphatases?}

Although CK2 appears to be a constitutively active enzyme, it is possible that the level of CK2-dependent phosphorylation of substrates may be regulated by phosphatases. Based on electrophysiological, pharmacological, and immunohistochemical evidence, Kv3.1 is present presynaptically at the MNTB synapse (Perney et al., 1992; Wang and Kaczmarek, 1998; Wang et al., 1998b). However, presynaptic potassium current recordings at this synapse, from a holding potential of $-40 \mathrm{mV}$ result in little sustained outward current, whereas depolarization from more negative holding potentials results in an outward current that is sensitive to $1 \mathrm{~mm}$ TEA (L. Y. Wang, I. D. Forsythe, and L. K. Kaczmarek, unpublished observation). This result would be expected if there were less phosphorylation of Kv3.1 CK2 sites in the presynaptic terminal. Differences between the native Kv3.1 current and those recorded in heterologously expressed cells may be attributed to coassembly with other members of the Shaw-like subfamily or interaction with auxiliary subunits. Our findings suggest that differences in native currents found in the presynaptic calyx of Held could also be attributed to differences in the phosphorylation state of the channel.

\section{REFERENCES}

Allende JE, Allende CC (1995) Protein kinases 4 Protein kinase CK2: an enzyme with multiple substrates and a puzzling regulation. FASEB J 9:313-323.

Allende CC, Allende JE (1998) Promiscuous subunit interactions: a possible mechanism for the regulation of protein kinase CK2. J Cell Biochem [Suppl] 30-31:129-136.

Blanquet PR (2000) Casein kinase 2 as a potentially important enzyme in the nervous system. Prog Neurobiol 60:211-246.

Brew HM, Forsythe ID (1995) Two voltage-dependent $\mathrm{K}+$ conductances with complementary functions in postsynaptic integration at a central auditory synapse. J Neurosci 15:8011-8022.

Critz SD, Wible BA, Lopez HS, Brown AM (1993) Stable expression and regulation of a rat brain K channel. J Neurochem 60:1175-1178.

Dobrowolska G, Lozeman FJ, Dongxia L, Krebs EG (1999) CK2, a protein kinase of the next millennium. Mol Cell Biochem 191:3-12.

Fenwick EM, Marty A, Neher E (1982) Sodium and calcium channels in bovine chromaffin cells. J Physiol (Lond) 331:599-635.

Grissmer S, Nguyen N, Aiyar J, Hanson DC, Mather RJ, Gutman GA, Karmilowicz J, Auperin DD, Chandy KG (1994) Pharmacological characterization of five cloned voltage-gated K channels, types Kv1.1, $1.2,1.3,1.5$, and 3.1 , stably expressed in mammalian cell lines. Mol Pharmacol 45:1227-1234.

Isakoff EY, Jan YN, Jan LY (1991) Putative receptor for the cytoplasmic inactivation gate in the Shaker K channel. Nature 353:86-90.

Kanemasa T, Gan L, Perney TM, Wang LY, Kaczmarek LK (1995) Electrophysiological and pharmacological characterization of a mam- malian Shaw channel expressed in NIH 3 T3 fibroblasts. J Neurophysiol 74:207-217.

Lieberman DN, Mody I (1999) Casein kinase-II regulates NMDA channel function in hippocampal neurons. Nat Neurosci 2:125-132.

Luneau CJ, Williams JB, Marshal J, Levitan ES, Oliva C, Smith JS, Antanavage J, Folander K, Stein RB, Swanson R, Kaczmarek L, Buhrow SA (1991) Alternative splicing contributes to K+ channel diversity in the mammalian central nervous system. Pro Natl Acad Sci USA 88:3932-3936.

Macica CM, Wang LY, Joho RH, Ho CS, Kaczmarek LK (2000) Knockout of the Kv3.1 gene impairs high frequency firing in auditory neurons. Soc Neurosci Abstr 26:1705.

McCormack K, Tanouye MA, Iverson LE, Lin J, Ramaswami M, McCormack T, Campanelli JT, Matthew MK, Rudy B (1991) A role for hydrophobic residues in the voltage-dependent gating of Shaker K+ channels. Proc Natl Acad Sci USA 88:2931-2935.

Murakoshi H, Shi G, Scannevin RH, Trimmer JS (1997) Phosphorylation of the Kv21 K+ channel alters voltage-dependent activation. Mol Pharmacol 52:821-828.

Oliva C, Cohen IS, Mathia RT (1988) Calculation of time constants for intracellular diffusion in whole cell patch clamp configuration. Biophys J 54:791-799.

Perney TM, Kaczmarek LK (1997) Localization of a high threshold potassium channel in the rat cochlear nucleus. J Comp Neurol 386:178-202.

Perney TM, Marshall J, Martin KA, Hockfield S, Kaczmarek LK (1992) Expression of the mRNAs for the Kv31 potassium channel gene in the adult and developing brain. J Neurophysiol 68:756-766.

Perozo E, Bezanilla F (1990) Phosphorylation affects voltage gating of the delayed rectifier $\mathrm{K}+$ channel by electrostatic interactions. Neuron 5:685-690.

Perozo E, Bezanilla F, Dipolo R (1989) Modulation of K channels in dialyzed squid axons ATP-mediated phosphorylation J Gen Physiol 93:1195-1218.

Rettig J, Wunder F, Stocker M, Lichtinghagen R, Mastiaux F, Beckh S, Kues W, Pedarzani P, Schroter KH, Ruppersberg JP, Veh R, Pongs O (1992) Characterization of a Shaw-related potassium channel family in rat brain. EMBO J 11:2473-2486.

VanDonger AMJ, Frech GC, Drewe JA, Joho RH, Brown AM (1990) Alteration and restoration of $\mathrm{K}$ channel function by deletions at the $\mathrm{N}$ and C-terminal. Neuron 5:433-443.

Vega-Saenz de Miera E, Morena H, Fruhling D, Kentros C, Rudy B (1992) Cloning of ShIII (Shaw-like) cDNAs encoding a novel highvoltage-activating, TEA sensitive, type-A K channel. Proc R Soc Lond B Biol Sci 248:9-18.

Wang LY, Kaczmarek LK (1998) High-frequency firing helps replenish the readily releasable pool of synaptic vesicles. Nature 394:384-388.

Wang LY, Gan L, Forsythe ID, Kaczmarek LK (1998a) Contribution of the Kv3.1 potassium channel to high-frequency firing in mouse auditory neurones. J Physiology 509:183-194.

Wang LY, Gan L, Perney TM, Schwartz I, Kaczmarek LK (1998b) Activation of Kv3.1 channels in neuronal spine-like structures may induce local potassium ion depletion. Proc Natl Acad Sci USA 95:1882-1887.

Weiser M, Bueno E, Sekirnjak C, Martone ME, Baker H, Hillman D, Chen S, Thornhill W, Ellisman M, Rudy B (1995) The potassium channel subunit Kv31b is localized to somatic and axonal membranes of specific populations of CNS neurons. J Neurosci 15:4298-4314.

Zandomeni RO (1989) Kinetics of inhibition by 5,6-dichloro-1-beta-Dribof uranosylbenzimidazole on calf thymus casein kinase II. Biochem J $262: 469-473$ 